\title{
Development of Low Fat Khoa Utilizing Reconstituted Skim Milk and WPC
}

\author{
Vijaykumar $^{1}$, M. Venkatesh ${ }^{1}$ and Akshaykumar ${ }^{2 *}$ \\ ${ }^{1}$ (Dairy Technology), Dairy Science College, Bengaluru-24, India \\ ${ }^{2}$ (Animal Science), ICAR-Krishi Vigyan Kendra, Bidar-585403, India \\ *Corresponding author
}

\section{A B S T R A C T}

\begin{tabular}{|l|}
\hline Ke y w or d s \\
$\begin{array}{l}\text { Low fat khoa, } \\
\text { Reconstituted skim } \\
\text { milk and WPC }\end{array}$ \\
\hline Article Info \\
\hline $\begin{array}{l}\text { Accepted: } \\
\text { 20 May } 2020 \\
\text { Available Online: } \\
\text { 10 June } 2020\end{array}$ \\
\hline
\end{tabular}

In the present research an attempt was made to develop low fat Khoa. Khoa is the traditional Milk based material for preparation of various sweets like Peda, Burfi, Kalakhand etc. Due to increased life style, disorders like cardio-vascular diseases, diabetes, and hypertension, the acceptability of calorie rich food like traditional products has been reduced. So, in order to meet demand for such target population and also for all the base material Khoa has been made with low fat by replacing WPC with 70 per cent protein with has functionality of water binding, emulsification and gelation. It is rich in essential amino acid and also has antibacterial, antifungal properties which can be exploited in dairy industry for manufacture of products. WPC at 5, 10, and 15 per cent was used among which 5 per cent was accepted.

\section{Introduction}

India ranks first in global milk production with milk production of 187.7 MT (NCAER, 2019), at growth rate of 6.62 per cent per year. The per capita availability of milk in India during 2019 was 394 g/day and by 2023-24, it is estimated to increase to 592 g/day (NDDB, 2019).

Traditional dairy products are India's largest selling and most profitable segment in dairy industry after liquid milk, accounting for about 50 per cent of milk utilization. Many traditional dairy products particularly Khoabased sweets have enormous market presence and tremendous consumer base in India and overseas as well.

Among traditional dairy products, heat desiccated products have tremendous potential for value addition. Khoa, one of the most important heat desiccated product, which utilizes 7.0 per cent of total milk production in India. About 1 million tonnes of Khoa is produced annually in India (Rasane et al., 2015) and 520 billion Rupees market for Khoa based sweets with annual growth of 50 
billion INR. Khoa and Khoa based sweets and other ethnic sweets are produced by organized sector and also has strong potential in North American market estimated with US \$ 500 million during last decade, hence many attempts have been made to use different types of Khoa like Pindi to prepare Peda, Dhap for Gulabjamun, and Danedar for making Burfi and Kalakhand.

According to FSSR 2011, Khoa defined as Khoya, by whatever variety of names it is sold such as Pindi, Danedar, Dhap, Mawa or Kava, means the product obtained from cow or buffalo or goat or sheep milk or milk solids or a combination thereof by rapid drying. The milk fat content shall not be less than 30 per cent on dry weight basis of finished product. It may contain citric acid not more than 0.1 per cent by weight. It shall be free from added starch, added sugar and added coloring matter.

Khoa contains good amount of proteins, minerals, fat and lactose in addition to thatfatsoluble vitamins. Further utilization of khoa as base material for production of peda and kalakand increases value of the product. Peda, Kalakand and many Khoa based sweets are prepared throughout the country. These are prepared by mixing Khoa with about 30 per cent sugar which intern provides preservative effect, giving long shelf life (Aneja et al., 2002).

The changing lifestyle in affluent and technologically developed societies, diseases like Obesity, Diabetes and Cardiovascular diseases have become major health problems. India is one of the six countries of the capital IDF South East Asia region. 425 million people have diabetes in the world and 82 million people in the south east Asia region; by 2045 this will rise to 151 million. There were over $72,946,400$ cases of diabetes in India in 2017 (IDF, 2017).
It's the need of hour to create the low-fat food and dairy products for the needy diabetic and CVD patients without much affecting the taste and sweetness, in this context several low-fat dairy products are in the market, but still market for these products under established because of the myth of side effects.

According to National Council of Applied Economic Research (NCAER) the current carryover stock of Skim Milk Powder (SMP) is estimated at about 2 lakh tonnes, which is unlikely to be absorbed until end of 2019 . Milk powder is obtained by partial removal of water from milk. The fat or the protein content, or both of milk may be adjusted, only to comply with the compositional requirements in such a way that there should be no change in the whey protein to casein ratio of milk. The products should be free from added whey (ADPI, 2014).

Today food industries are looking for ingredients, which can provide functional and nutritional properties for formulation of various value-added food products. The food industry has come to realize that milk proteins in general and whey proteins in particular have potential to improve the quality of food products. Whey is one of the major and voluminous byproducts in the dairy industry and contains half of total milk solids. Thus, draining of whey not only amounts to loss of valuable nutrients but also increases environmental pollution due to presence of high organic matter and contains high biological oxygen demand 30,000 - 60,000 $\mathrm{ppm}$. An estimated more than $3 \mathrm{MT}$ of whey is produced by Indian dairy industries (Kumar et al., 2018).

WPC has high nutritional and functional properties such as foaming, solubility, emulsifying, gelling and water binding properties. It is widely being used in food 
sector for enriching various food formulations like frozen desserts, geriatric foods, yoghurt, processed cheese, infant formulae and in traditional dairy products and various bakery applications. Besides the nutritional and functional properties, whey protein also carries a bio-protective agent which enhances anti-inflammatory property, protection of intestinal flora with antibacterial or preservative effects and passive immunity against enteric, respiratory bacteria and viruses (Berber et al., 2015).

WPC could be used to replace dried skim milk solids in yoghurt without adverse effect on sensory properties. Utilization of WPC improves viscosity, gelation and water holding capacity and thereby it can be explored in some of the products like soup, yoghurt, Khoa (Soumyashree et al., 2017). Cutting across different regions of the Indian sub-continent, a number of heat desiccated milk confections are popular. These products are based on Khoa/Mawa, which is used as base material for sweets such as Peda, Burfi, Kalakand, Gulabjamun, Kalajamun, Milk cake, Peda, Rabri, Khurchan, Basundi, Pantua, Kunda and Lalmohan. Confections like Bal Mithai, Phirni, Kunthalgiripedha, Malaipoori, LalPeda, Dharwad Peda and Thirattupal are region-specific locally available sweets in different parts of India which are preferred by people for their characteristic taste and texture.

\section{Materials and Methods}

Fresh whole milk was procured from Students Experimental Dairy Plant (SEDP) of Dairy Science College, Hebbal, Bengaluru. Skim milk powder was purchased from milk parlour of Mother Dairy Bengaluru. Whey protein concentrate is of Lactoprot brand (80 per cent protein) purchased from online market. Packaging material used for packaging of low fat Khoa is LDPE pouches, polystyrene cups, HDPE pouches and Metalized polyester packaging materials procured from online market. Stainless steel vessels of varying capacities and stainless steel stirrers were used at various stages of the investigation. The vessels were washed by using detergents and kept for air dry. All the chemicals used in this investigation were of Analytical grade.

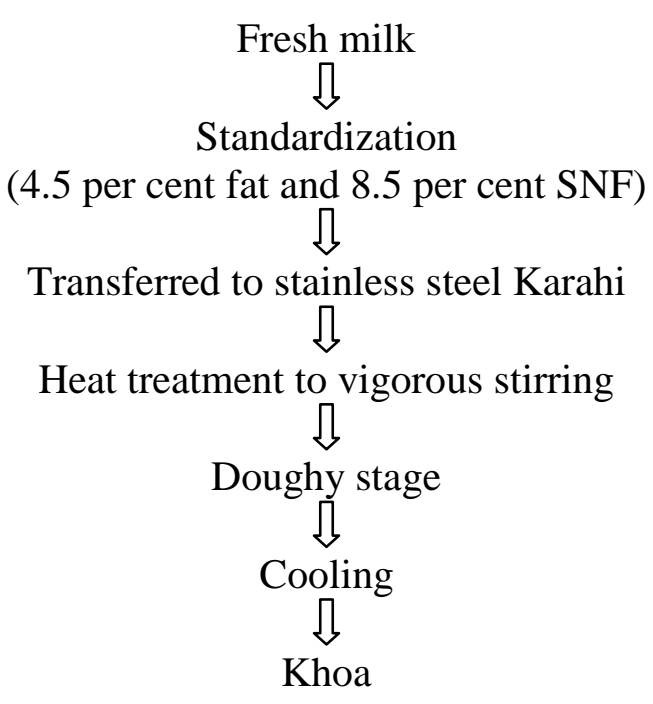

Flow Chart.1 Production of Khoa (Aneja et al., 2002) 
Reconstituted skim milk

Standardization

$(0.5,1.5$, or 3.0 per cent fat and SNF 9.0 per cent)

Addition of WPC

$(5,10$, or 15 per cent $)$

$\sqrt{ }$

Transferred to stainless steel Karahi

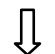

Heat treatment to vigorous stirring

గ

Doughy stage<smiles>[CH-]=C</smiles>

Cooling

Љ

Khoa

Flow Chart.2 Manufacturing low fat functional Khoa

\section{Results and Discussion}

Effect of different levels of fat in reconstituted skim milk on sensory quality of Khoa

The effect of different levels of fat in reconstituted skim milk on colour and appearance,body and texture, flavour and overall acceptability of khoa is presented in Table1 are discussed under here.

The highest colour and appearance score was awarded to control 8.10 and lowest score (7.50) was awarded to product prepared by 0.5 per cent fat in reconstituted skim milk. Among all the treated samples 3 per cent fat in reconstituted skim milk recorded best with respect to colour and appearance score (7.55). the milk fat level had no significant effect on colour and appearance scores of the control and treated samples.

There was significant $(p \leq 0.05)$ increase in the body and texture scores seen as fat level in reconstituted skim milk increases. The highest body and texture score was awarded for 3 per cent fat level treated sample (8.01) and lowest (6.49) for 0.5 per cent treated sample against control (8.30). Among all the samples, there was significant difference in scores of body and texture except control and sample treated with 3 per cent fat levels. The fat levels of 3 per cent accepted among various levels of fat treated samples with score 8.0 against control 8.50 respectively. As the fat levels decreased in milk the score for flavour decreased and lowest score (6.90) was awarded for 0.5 per cent treated sample. Therefore, this showed that there is significant difference in between the treated samples but except control and 3 per cent fat levels showed non-significant difference.

It is clear from Table 1 that, increase in sensory scores of overall acceptability of khoa when fat content was used upto 3 per cent. Further decrease in fat content to prepare low fat khoa the sensory scores affects the overall acceptability. The findings from observations made by Vijendra, (2006) reported that 3.00 per cent fat content had highest sensory score and was acceptable during preparation of low calorie enriched diabetic Sandesh. From this it is evident that, use of 3 per cent fat level in the preparation of low fat khoa was beneficial. Dhage et al., (2018) prepared peda 
with different levels 4.5 per cent showed overall acceptability of 8.75 and as fat levels decreased the sensory score also decreased.

Effect of adding various levels of whey protein concentrate (WPC) on sensory characteristics of Khoa

The khoa was manufactured by replacing fat with WPC at 5, 10, and 15 per cent level and its effects on sensory characteristics of khoa is presented in Table 2.0

The highest colour and appearance score was awarded to sample treated with 5 per cent WPC (8.11) and lowest score was awarded to the product prepared by incorporating WPC at 15 per cent (7.9). Among the treated samples 5 per cent added WPC khoa recorded best colour and appearance score 8.11 against control 8.10 respectively. As WPC levels increased the colour and appearance scored decreased in khoa. Similar observations were made by Venkatesh (2018) and soumyashree (2017) in Shrikhand and mistidahi respectively. The results showed that there was non-significant effect on levels of WPC incorporation on colour and appearance scores of khoa.

Sensory scores of control were 8.20 as against 8.00 of khoa with 5 percent WPC for body and texture and lowest (7.00) for 15 per cent. The decrease in sensory score for body and texture is seen as increase in the WPC levels. Although the sample with 5.00 per cent has no significant effect on body and texture but as WPC levels increased the product consistency of body and texture of treated products became pasty at higher levels, this may be due to more water retention property by whey proteins when heat treated.WPC levels upto 5 per cent positively influenced the physical properties of khoa. Praveen, (2018) reported results that 25 per cent replacement of fat gave higher body and texture scores and increase in level of WPC replaced with fat showed decrease in sensory scores of body and texture.

Table.1 Effect of different levels of fat in reconstituted skim milk on sensory quality of Khoa

\begin{tabular}{|c|c|c|c|c|}
\hline Level of Fat(\%) & $\begin{array}{c}\text { Colour and } \\
\text { Appearance }\end{array}$ & $\begin{array}{c}\text { Body and } \\
\text { Texture }\end{array}$ & Flavour & $\begin{array}{c}\text { Overall } \\
\text { Acceptability }\end{array}$ \\
\hline Control & $8.10^{\mathrm{a}}$ & $8.20^{\mathrm{a}}$ & $8.50^{\mathrm{a}}$ & $8.30^{\mathrm{a}}$ \\
\hline $\mathbf{0 . 5}$ & $7.50^{\mathrm{a}}$ & $6.49^{\mathrm{b}}$ & $6.90^{\mathrm{b}}$ & $6.92^{\mathrm{b}}$ \\
\hline $\mathbf{1 . 5}$ & $7.52^{\mathrm{a}}$ & $6.34^{\mathrm{c}}$ & $7.0^{\mathrm{b}}$ & $7.02^{\mathrm{b}}$ \\
\hline $\mathbf{3 . 0}$ & $7.55^{\mathrm{a}}$ & $8.0^{\mathrm{a}}$ & $8.0^{\mathrm{a}}$ & $8.01^{\mathrm{a}}$ \\
\hline $\mathbf{C D}(\boldsymbol{p} \leq \mathbf{0 . 0 5})$ & 0.46 & 1.027 & 0.62 & 0.146 \\
\hline
\end{tabular}

Table.2 Effect of adding various levels of whey protein concentrate (WPC) on sensory characteristics of Khoa

\begin{tabular}{|c|c|c|c|c|}
\hline $\begin{array}{c}\text { Level of WPC } \\
(\%)\end{array}$ & $\begin{array}{c}\text { Colour and } \\
\text { Appearance }\end{array}$ & $\begin{array}{c}\text { Body and } \\
\text { Texture }\end{array}$ & Flavour & $\begin{array}{c}\text { Overall } \\
\text { Acceptability }\end{array}$ \\
\hline Control & $8.10^{\mathrm{a}}$ & $8.20^{\mathrm{a}}$ & $8.50^{\mathrm{a}}$ & $8.30^{\mathrm{a}}$ \\
\hline $\mathbf{5 . 0}$ & $8.11^{\mathrm{a}}$ & $8.22^{\mathrm{a}}$ & $8.0^{\mathrm{a}}$ & $8.17^{\mathrm{a}}$ \\
\hline $\mathbf{1 0}$ & $8.0^{\mathrm{a}}$ & $7.50^{\mathrm{b}}$ & $7.10^{\mathrm{b}}$ & $7.10^{\mathrm{b}}$ \\
\hline $\mathbf{1 5}$ & $7.90^{\mathrm{a}}$ & $7.0^{\mathrm{c}}$ & $7.0^{\mathrm{b}}$ & $7.0^{\mathrm{b}}$ \\
\hline $\mathbf{C D}(\boldsymbol{p} \leq \mathbf{0 . 0 5})$ & $\mathrm{NS}$ & 0.45 & 0.81 & 0.14 \\
\hline
\end{tabular}

The values are average of three trials; Superscripts indicate significant differences in values 


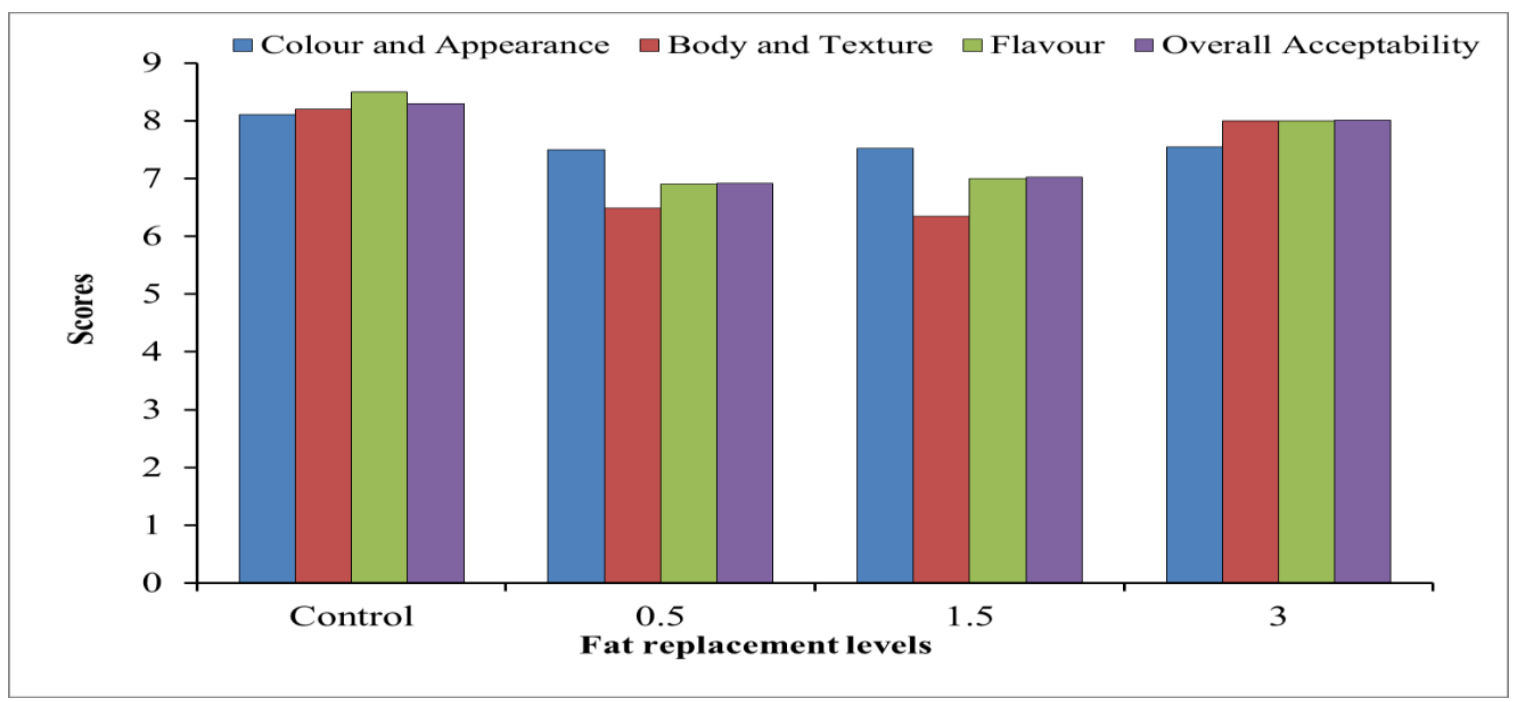

Figure.1 Effect of different levels of fat in reconstituted skim milk on sensory quality of khoa

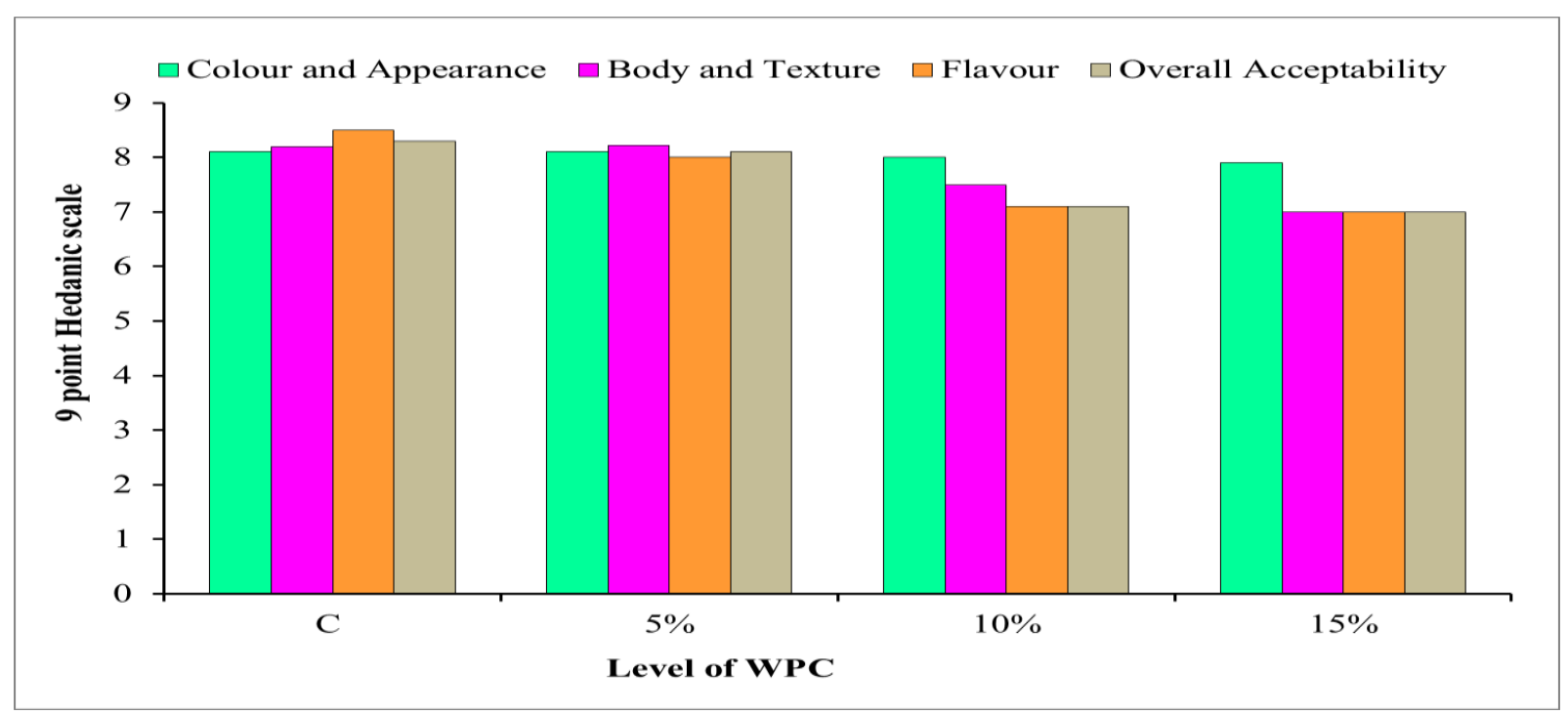

Figure.2 Effect of adding various levels of whey protein concentrate (WPC) on sensory characteristics of Khoa

The maximum flavour score awarded for control khoa (8.50) whereas, minimum flavour score 7.0 was awarded for 15 per cent WPC addition. Among all treated sample 5 per cent WPC levels secured flavour score of (8.0). There was $(p \leq 0.05)$ significant decrease in the flavour scores was recorded with increase in WPC addition. Similar results were obtained by Jayaprakasha (2000), where yoghurt prepared by incorporating with WPC at higher levels secured lower sensory scores with respect to flavour.
The sensory scores for overall acceptability 8.10 is seen for sample with 5.00 per cent WPC against control 8.30 which was comparable. Decrease in sensory score for overall acceptability is seen as increase in level of WPC level is seen. Similar findings were obtained by Soumyshree (2017), in the preparation of enriched mistidhai where 6 per cent levels of WPC secured lowest sensory scores with respect to overall acceptability.

Although the sample with 5 per cent has no 
significant effect on body and texture but as WPC levels increased the product consistency of body and texture of treated products became pasty at higher levels, this may be due to more water retention property by whey proteins when heat treated.WPC levels upto 5 per cent positively influenced the physical properties of Khoa.

\section{References}

Adpi, 2014. American Dairy Products Institute. www.adpi.org

Aneja, R.P., 2002. Technology of Indian milk products. Dairy India Year Book. A Dairy India Publication, New Delhi. India

Berber, M., González-Quijano, G.K. and Alvarez, V.B. 2015. Whey Protein Concentrate as a substitute for non-fat dry milk in yogurt. J. Food Process Technol., 6(12): 222-228.

Boirie, Y., Dangin, M., Gachon, P., Vasson, M.P., Maubois, J.L. and Beaufrere, B. 1997. Slow and fast dietary proteins differently modulate postprandial protein accretion. Proclamations of National Academy of Sciences, 94: 14930-14935.

De, S., 1980. Outlines of Dairy Technology. Oxford University Press. New Delhi, India.

Dhage, D.A., Londhe, G.K., Kamble, N.S. and Godage, S.H., 2018. Studies on effect of fat levels on sensory quality of peda. Bull. Env. Pharmacol. Life Sci., 7(3): 16-18

FSSR 2011, Food Safety and Standard Regulation. New Delhi, India

IDF, 2017. International Diabetes Federation www.idf.org

Jayaprakasha, H.M., 2000. Whey protein concentrate in the formulation of dairy and bakery products. Final report of adhoc scheme, report submitted to ICAR, New Delhi.

Kumar, R., Chauhan, S.K., Shinde, G., Subramanian, V. and Nadanasabapathi, S., 2018. Whey Proteins: A potential ingredient for food industry-A review. Asian J. Dairy \& Food Research, 37(4):283-290

NCAER., 2019.National Council of Applied Economic Research. www.ncaer.org

NDDB., 2019. National Dairy Development Board.www.nddb.coop

Praveen, A.R. 2018. Development of low calorie Khoa and Khoa based sweets. $\mathrm{Ph} . \mathrm{D}$ thesis submitted to Karnataka Veterinary, Animal and Fisheries Sciences University, Bidar, India.

Rasane, P., Tanwar, B. and Dey, A., 2015. Khoa: a heat desiccated indigenous Indian dairy product. Research journal of pharmaceutical biological and chemical sciences, 6(5):39-48.

Soumyashree, T.C., Venkatesh, M., Praveen, A.R. and Teja, V., 2017. Effect of whey protein concentrate and fruit juice on sensory quality of enriched Mistidahi. Asian J. Dairy \& Food Res., 36(1): 236242.

Venkatesh, M., Soumyashree, T.C. and PRAVEEN, A.R., 2018. Prolonging shelf life of enriched shrikhand under MAP: effect on chemical and microbiological qualities. International Journal of Chemical Studies, 6(2): 2376-2385.

Vijayendra Kumar, P.N., 2006. Development of low calorie enriched diabetic sandesh. M.Tech Thesis submitted to Karnataka Veterinary, Animal and Fisheries Sciences University, Bidar, India.

\section{How to cite this article:}

Vijaykumar, M. Venkatesh and Akshaykumar. 2020. Development of Low Fat Khoa Utilizing Reconstituted Skim Milk and WPC. Int.J.Curr.Microbiol.App.Sci. 9(06): 2661-2667. doi: https://doi.org/10.20546/ijcmas.2020.906.324 